\title{
The Impact of Education and Training, Work Discipline and Organizational Culture on Employee's Performance: The Study of Disaster Management and Fire Department in Palembang City, Indonesia
}

\author{
Muhammad Idris \\ Universitas Muhammadiyah Palembang, Indonesia
}

Received: April 16, 2018 Accepted: May 8, 2018 Online published: May 13, 2018

doi:10.5296/ijhrs.v8i3.13013ＵRL: https://doi.org/10.5296/ijhrs.v8i3.13013

\begin{abstract}
This study aims to investigate the impact of education and training, work discipline and organizational culture on employee's performance. The study is conducted at the Disaster Management and Fire Department Office in Palembang City, Indonesia. There are seven offices of disaster management and fire department officials in all over Palembang city and the total population is 360 firefighters. The sample size is 154 respondents that are taken proportionately from each office. A survey research using questionnaire is employed to collect the data. The variables are education and training (X1), work discipline (X2), organizational culture (X3) and employees' performance (Y). Technology and labor force changes, service and performance improvement and rules' adjustment are indicators for education and training. Remuneration, supervision, and firmness are indicators for work discipline. Innovation, people oriented and composure are indicators for organizational culture. Working standard, work equipment and tool and work opportunity are indicators for employees' performance. A regression equation model is employed. The result reveals that there is a positive and significant effect of education and training, work discipline and organizational culture on employee's performance.
\end{abstract}

Keywords: Education and training, work discipline, organizational culture, employees' performance, Indonesia

\section{Introduction}

The government has done several ways of providing services to the community, one of the provision of services to the community about the disaster. Palembang city government through the Mayor of Palembang assigned to the Disaster Management Agency and Fire 
Department of Palembang City to provide services directly related to the community. These services include Prevention \& Preparedness, Emergency \& Logistics, and Rehabilitation \& Reconstruction. The division of tasks is done so that the community is protected from the danger of fire.

The frequent occurrence of fire in the homes of the population due to the number of community houses made of semi-permanent materials such as dried wood and plywood which is certainly easy to cause a fire. In addition, adjacent community houses can facilitate the propagation of fire from house to house not infrequently only a meter, so that in a short time the fire has occurred and the fire has been enlarged. When there is a large fire, the fire team is difficult to tame the fire in a fast time but it takes patience, willpower, and hard work. Firefighters are said to be able to extinguish the fire when it is fast, precise, effective and efficient but if the fire team arrives late to the scene of the fire and the fire has spread, propagates and extends around the fire site it can be said that the firefighters failed in a duty. Especially for late arrivals can be caused by many factors that one of them is stuck on the highway and late getting fire information. It is said to succeed in tackling the fire accident actually happened because of a good relationship between firefighting team and the surrounding community who experienced the disaster and the supporting equipment in tackling the disaster, the equipment could be from the Fire Department as well as from the community.

Firefighters are basically established to cope with the fire disaster and other calamities that are humanitarian. The calamities must be addressed properly, quickly, appropriately, effectively and efficiently. In the mandate of the preamble of the 1945 Constitution which reads ".... protecting the whole nation of Indonesia", protecting words is the government's efforts in realizing a society protected from the threat of fire and other calamities.

In managing the quality of human resources itself can be seen through its performance, so performance management or often known as performance management is about how to manage activities within an organization to achieve organizational goals. Implementing performance management will benefit organizations, teams, and individuals. Performance management supports the organization's overall objectives by linking the work of each worker and manager to the overall work unit. Workers play a key role in organizational success. How well a leader manages the performance of subordinates will directly affect the performance of individuals, work units, and the entire organization.

According to Wibowo (2016), performance management is the management of creating relationships and ensuring effective communication. Performance management focuses on what organizations, managers, and workers need to succeed. Performance management is about how performance is managed to gain success. Performance comes from the notion of performance. There is also a definition of performance as a result of work or work performance. However, performance actually has a broader meaning, not the result of work, but including how the work process takes place.

Thus, it can be interpreted that optimal and stable performance, is not a coincidence. Certainly already through the stages with good performance management, and the maximum 
effort to achieve it. Without good performance management, it is possible that the results are proudly pseudo, so, success is a coincidence that is not based on a strong foundation (Edison, Anwar and Komariyah, 2016).

The success of an organization in achieving goals and challenges is determined by the ability to manage human resources and this is the most important element in an organization. Human Resource Management itself can be defined as the whole process of planning, organizing, directing, and supervising the procurement activities of selection, training, placement, compensation, development, integration, maintenance and release of human resources for the achievement of individual, community, government and organizational goals concerned. According to Edison, Anwar and Komariyah (2016), Human resource management is a management that focuses on maximizing the ability of employees or members through various strategic steps in order to improve the performance of employees towards optimization of organizational goals.

The Disaster Management and Fire Agency (BPB-PK) of Palembang City, which is one of the official work units of SKPD, is located in the city of Palembang. The performance of firefighters of Palembang city until now has not been maximal, so the service to the community felt less satisfactory. Some of these problems include (1) Firefighters are often late arriving at the scene of the fire accident, as the information obtained is also delayed by the distance from the post to the remote location; (2) Firefighters are less alert in using the tools used in performing blackout operations; (3) Firefighters stutter the technology in using the equipment to be worn such as using breathing apparatus because a firefighter is less educated how to use the tool; (4) Lack of good cooperation between firefighters and the community in terms of tackling the disaster. Based on the problems that occurred above, it is necessary to improve the performance of firefighters of Palembang city, needed suggestions from the community and from related offices including TNI and Polri. Performance improvements are made thoroughly and continuously from time to time to better fire extinguishing performance.

In addition, there are some issues causing the cause of the fire caused by the negligence of the community itself, such problems are: Community homes are generally made of wood, plywood and combustible materials besides the distance between the houses adjacent so easily spread if there is a fire. Generally, the incident is caused by the carelessness of the community itself or human error, such as forgot to turn off the stove, forgot to turn off electrical equipment, electrical equipment used not in accordance with existing electrical standards. Access pointed to the location of the disaster sometimes get blocked like jams, away from the main road, and at the scene of the fire of the fire people are fussed up angry not infrequently seize the fire hose equipment, of course, the blackout operation is hampered can be ascertained consequently the blackout operation takes a long time.

The firefighter is one of the elements of the state civil apparatus whose task is to overcome the disaster and the fire accident, therefore the city government of Palembang needs to educate train, discipline and form a strong organizational culture in order to create a reliable, tough, cultured firefighter apparatus, better and more focused on the work. 


\section{Mll Macrothink}

The training education aims to enable firefighters on duty to work quickly, accurately, completely and effectively and efficiently. Understanding of the equipment to be used in the event of a fire accident is a must for firefighters. Wearing using personal protective equipment is also a must so that when on duty firefighters protected themselves from accidents arising on duty. Fire fighters (education fighter) is a special training education for new firefighters or beginners.

The new firefighters are required to follow the training of fire fighter training in order to create good work as expected. Good work effective and efficient is expected by the people of Palembang city. Disaster Management Agency and Fire Department of Palembang City has a mission to realize the creation of the city of Palembang a safe and comfortable from the danger of fire. However, the phenomenon that occurs in the field of firefighters is less nimble in carrying out operations in the fire accident, due to lack of training education owned by firefighters. Minimal training education can lead to the performance of firefighters so slow, due to the slow in extinguishing the fire the greater the loss. One of the perceived impacts of the people is the loss of jobs or livelihoods, the incidence of crime increases and many more losses caused by the fire accident. In addition to the above training education, the discipline also affects the performance of firefighters. Discipline is the attitude of one's willingness and willingness to obey and obey the norms of the prevailing rules around it (Sutrisno, 2016). Good employee discipline will accelerate the company's goals, while discipline degenerates into obstacles and slows the achievement of corporate goals.

The discipline of a firefighter can be seen from, in and out of work on time, doing the job well and correctly. Discipline can also be interpreted if firefighters do all their work well, comply with all official regulations and social norms. The discipline of firefighters can also be seen from them wearing personal protective equipment while on duty to extinguish the fire. The phenomenon that often occurs in the field is the frequency of firefighters do not use personal protective equipment and they are often reminded by the field leaders to wear personal protective equipment at the time of the disaster, not infrequently firefighters get tragedy in working like a head injured for not wearing a helmet, hand injured for not wearing gloves, legs unharmed for not cursing shoes and so forth. In addition, firefighters are often late in entering the work so that if there is fire information lack of personnel to the location of the incident.

Corporate culture (corporate culture) is often exchanged or equated with the term organization culture (organization culture). Organizational culture is the result of a process of diluting and incorporating the cultural style and/or behavior of each individual brought beforehand into a new norm and philosophy, which has the energy and pride of the group in the face of something and a particular purpose (Edison, Anwar and Komariyah, 2016).

Organizational culture is the way people do things in organizations. Between the organizational cultures with human resources there are relationships that are mutually influential. Organizational culture is formed from a group of people who have a strong desire to achieve organizational goals. Focusing on improving the organizational culture will directly affect the firefighter's workforce so that it can trigger professional performance of 
firefighters and organizational goals is well achieved.

Firefighters may not work alone and / or in groups to perform fire extinguishing operations because they are not good for the organization's sustainability. The firefighter's actions should help the colleague on duty when needed and see what conditions the condition should be seconded to the smooth operation of extinguishing the fire. Generating quality human resources requires systematic and targeted efforts, including through proper training education, correct work discipline and supported by a good organizational culture in order to create good performance. With the training education, work discipline, good organizational culture will be able to influence the performance of firefighters at the office of the Disaster Management and Fire Agency of Palembang City.

\section{Literature Review}

\subsection{Education and Training}

Training can be defined as a planned undertaking of an organization to improve the knowledge, skills, and abilities of employees (Hariandja, 2009). However, conceptual training can also change employee attitudes toward work. This is due to the employee's understanding of his work is also changing, because the attitude of a person has cognitive elements of one's beliefs and knowledge of an object, the affection of a person's feelings towards the object as a result of his knowledge and belief, and the tendency of action towards the object, obtained will be able to change one's attitude.

There are several reasons why training education should be done from human resource management activities: Newly recruited employees often do not yet understand exactly how to do the job. Changes in the work environment include changes in technology and labor. Improve the competitiveness of enterprises, employee performance, improve productivity and service to the community. Adjust the rules to ensure the safety and health of employees. According Sedarmayanti (2014) training is an effort to reduce or eliminate the occurrence of gaps between the ability of employees with the desired organization. The effort is done through the improvement of work skills owned by employees/firefighters by adding knowledge and skills and changing attitudes. Firefighters are the most valuable organizational wealth because, with all its potential, firefighters can continue to be trained, so as to be more efficient, achievement becomes more optimal to achieve organizational goals.

The existence of a gap between the firefighter's ability and the desired organization led to the need for an organization to bridge the gap, one way of training. It is expected that all the potential of a firefighter, that is knowledge, skill and attitude can be improved, finally the gap will decrease or not happened again the gap. Basically a training program is organized with the aim of reducing or eliminating the gap between the terms of position and the capabilities of firefighters. Training should be able to improve knowledge, skills and change the behavior of firefighters according to the needs of the organization.

Training education is conducted to change the attitude of firefighters in an effort to improve service and performance to the community. Viewed from the objectives of training education is emphasized on improving the knowledge and ability to do work in the future, which is 
done through an integrated approach with other activities to change the work behavior of firefighters. Judging from the execution period, training as part of the development task can be divided into three, namely: Pre-service training is the training given to prospective employees who will start work, or new employees who are debriefing so that they can perform the tasks that will be charged to them. In-service, training is training in tasks performed for employees who are on duty in the organization with the aim of improving the ability to carry out the work.

Post service training is an organizational training to assist and prepare employees in the face of retirement, for example, Entrepreneurship training. Training farms, agriculture, and others Performance-related training provides space for the development and upgrading of skills and competencies that can have a direct impact on the individual or team performance (Dharma, 2015). This is relevant training in the sense that it is directed to improve performance in areas where the need to achieve better outcomes has been clearly identified. The goal is to identify individual training needs and provide relevant and effective training to meet them.

\subsection{Work Discipline}

Work discipline is a tool used by managers to communicate with employees in order to be willing to change a behavior as well as an attempt to increase a person's awareness and willingness to comply with all corporate rules and prevailing social norms. The order is the main characteristic of organization and discipline is one of the methods to maintain that order (Sutrisno, 2016). The main goal of discipline is to improve efficiency as much as possible by preventing the waste of time and energy. In addition, discipline tries to prevent damage or loss of property, machinery, equipment and work equipment caused by inadvertence, banter or theft. Discipline tries to overcome mistakes and negligence caused by lack of attention, disability, and delay. Discipline seeks to prevent the onset of slow or overt work at the beginning of work due to delays or laziness. Discipline also seeks to overcome differences of opinion among employees and prevent disobedience caused by misunderstanding and misinterpretation.

Another opinion about the discipline factors that affect performance is proposed by Armstrong and Baron in Wibowo (2016), which states that personal factors, indicated by the level of skill, competence, motivation, and individual commitment.) Individual commitment is the desire/the great desire of firefighters in the work can be realized with good work discipline. According to Hasibuan (2010) states that Discipline is the awareness and willingness of employees to comply with all corporate rules and prevailing social norms. Awareness is the attitude of firefighters who voluntarily obey all rules and are aware of their duties and responsibilities. So, he will obey/do all his work well, not for coercion. Willingness is an attitude, behavior, and deed of firefighters in accordance with official regulations, whether written or not.

Regulations are necessary to provide guidance and counseling for employees in creating good corporate governance. With good discipline, morale, work morale, efficiency, and effectiveness of employees will increase. This will support the achievement of corporate, employee and community goals. Obviously, the company is difficult to achieve its goals if 
employees do not comply with the rules of firms. The discipline of a company is said to be good if most employees obey the rules. Discipline must be enforced within an organization. Without the support of good employee discipline, it is difficult for the company to realize its objectives. There are several indicators that affect the level of employee discipline (firefighters) of an organization (Hasibuan, 2010) including Goals and Capabilities, The purpose (work) charged to firefighters must be in accordance with the capabilities of the firefighter in question, in order for him to work diligently and discipline in working on them.

\subsection{Organizational Culture}

Culture is defined as the way of life of people who are transferred from generation to generation through various learning processes to create a particular way of life that best suits their environment. Culture is a common basic assumption pattern that groups learn through solving external adaptation problems and internal integration. A group of organized people who have the same goals, beliefs, and values, and can be measured by their influence on motivation. The application of such culture within the organization into an organizational culture. Like it or not, we are immersed in a work culture. Whether important or not, customs and cultural norms will determine what we do from day to day and determine how we think. Appropriate or not is not a matter of choice, unless we want to get out. Corporate culture permeates into our pores and establishes identity. Managers who are uncomfortable with cultural notions should be careful. Culture, not formal rules or wisdom, mainly determine what we can and cannot do. Because culture is a key factor that affects successful or failing companies, it needs to be included in the list of high management priorities.

There are seven elements that show the characteristics of organizational culture according to Wibowo (2016), namely: Innovation, a level where people are expected to be creative and generate new ideas. Stability, respectful of a stable, predictable, and regulatory environment. Orientation to people is an orientation, to be honest, supportive, and show respect for individual rights. Orientation to the outcome, putting its power on its care to achieve the expected result. Be calm, a situation where the creation of a working climate is relaxed. Attention to detail, intended with an interest to be analytical and thorough. Orientation to collaboration, an orientation that emphasizes working in teams as opposed to working individually.

An organization is usually formed to achieve a certain goal through the performance of all human resources in the organization. However, the performance of human resources is largely determined by internal and external organizational conditions, including organizational culture. Therefore, the ability to create an organization with a culture that is capable of driving performance is a necessity. Between the organizational cultures with human resources there are relationships that are mutually influential. Organizational culture is shaped by the founders and leaders of the organization and in turn the organizational culture will affect the human resources that enter into it, but it is possible that the entry of new resources can affect organizational culture changes (Wibowo, 2016). Thus, organizational culture is not static, just like humans, organizational culture with time travel will grow to become more mature. A more mature organizational culture will be better able to adapt to 
changes in the environment, an organization will be able to realize a culture that can encourage organizational performance to achieve its goals. Achieving culture is an organizational culture that is oriented towards improving the achievement of human resources in the organization.

According to Edison, Anwar and Komariyah (2016), this organizational culture becomes important, be it for government organizations, business, school, college and so forth. Therefore, organizational culture provides a framework related to the behavior of members (employees / teachers / lecturers) and work climate. If the organizational culture is strong, the existing members of the organization regard the rule as no longer a shackling obligation, but a necessity. On the other hand, they have a sense of togetherness, kinship and pride in their organization which in turn fosters members' satisfaction and commitment, which is why culture is important to manage.

A strong organizational culture shows that the core values of the organization are firmly held and shared. The more members of the organization that receives core values and the greater their commitment to those values, the stronger the organizational culture. Strong organizational culture will affect the behavior of members of the organization because high levels of togetherness and intensity will create an internal atmosphere of high behavior control. Also described by Sunyoto and Burhanudin (2011), organizational culture can be strong may also be weak, depending on various influencing factors such as cohesiveness, consensus values, and individual commitment to common goals. A strong but persisting culture of change can be a bad thing from a competitive standpoint and profitability, rather than a weak but innovative culture.

\subsection{Performance}

Performance comes from the notion of performance. There is also a definition of performance as a result of work or work performance. However, performance actually has a broader meaning, not just the work, but includes how the work process takes place. Performance is the result of work that has a strong relationship with the organization's strategic goals, community satisfaction, and contribute to the government. Performance is about what to do and how to do it. According to Wibowo (2016), the factors that drive performance are behavior. Behavior is how you act (how you act), and not about what or who you are (what you are or who you are). Behavior is a way in which a person acts or performs. Because it can determine what will be done in every situation, you can determine your performance. High-level performance is the result of doing something right at the right time. An organization is formed to achieve a certain goal. Goals are something the organization expects to achieve. Organizational goals can include improving customer service, fulfilling market/community demand, improving product or service quality, increasing competitiveness, and improving the performance of the organization. Each organization, team, or individual can set its own goals.

Here are seven performance indicators according to Wibowo (2016), namely; purpose, standard, feedback, tools, competence, motives, and opportunities. The purpose is a better state to be achieved in the future. Standard is a measure of whether the desired goal can be 
achieved. Without a standard, it cannot be known when a goal is reached. Between objectives, standards, and feedback are interrelated. Feedback reports progress, both quality, and quantity, in achieving the goals defined by the standards. Tool or means is a supporting factor for the achievement of goals. Without the tools, it is impossible to do the job. Competence allows one to accomplish tasks related to the work required to achieve the goal. Motives are reasons or incentives for someone to do something. Firefighters need to get a chance to show their work performance. Performance within an organization is done by all human resources in the organization, both elements of leadership and workers. Lots of factors that affect human resources in running its performance. There are factors that come from within the human resources themselves and from outside himself.

Each worker has skills based on knowledge and skills, competence appropriate to his job, work motivation, and job satisfaction. However, workers also have personalities, attitudes, and behaviors that can affect their performance according to Wibowo (2016). However, the performance of an organization is not only influenced by human resources in it, but also by other resources such as funds, understanding, equipment, technology, and working mechanisms that take place within the organization. The effectiveness of each action depends on the situation. Effective performance in work is the result of doing the right thing at the right time or the right thing for a specific job at that specific point in time).

Research conducted by Kowaas, Sepang and Taroreh (2016) in research entitled Influence of Education, Training, and Work Discipline on Employee Performance at Regional Disaster Management Agency of North Sulawesi Province. In this study population amounted to 81 people and the sample amounted to 44 respondents. Where are the variables Education (X1), Training (X2), Work-Discipline (X3) and Employee Performance (Y)? Based on test results proved that the results of simian analysis simultaneously education, training and work discipline have a significant effect on employee performance because the level of significance shown is smaller than 0.05 is 0.002 .

Research conducted by Aulia (2014) in a study entitled "The Effect of Education and Training, Job Satisfaction, and Leadership on the Performance of Inpatient Nurses in Siak District Hospital". In this study population and sample amounted to 67 people. Where are the variables of education and training (X1), job satisfaction (X2), leadership (X3) and nurse performance $(\mathrm{Y})$ ? Based on test results proved that the variables of education and training, job satisfaction, leadership together affect the nurse's performance of $38.9 \%$ while the rest of $61.93 \%$ influenced by other factors not examined.

The study was conducted by Gultom (2014) in a study entitled "The Influence of Corporate Organizational Culture and Motivation on Employee Performance at PT. Perusahaan Gas Negara (Persero) Tbk Medan ". In this study, the population used amounted to 100 people as well as samples. Where the organizational culture variable (X1), motivation (X2), employee performance $(\mathrm{Y})$. The result of the research, there is significant influence between organizational culture (X1) and motivation (X2) on employee performance (Y) shown by $\mathrm{F}$ test with $\mathrm{F}$ value is 15.710 with significant level 0.000 . This means that independent variables organizational culture (X1) and motivation (X2) there is a significant influence on the 
dependent variable employee performance (Y). Where Ho is accepted if Fcount $>$ Ftable at $\alpha$ $=5 \%, \mathrm{Ha}$ is accepted if Fcount $>$ Ftable is $15.710>3.090$ and the significance level $(0,000)$ $<0.005$ indicates that the influence of independent variable (Organizational Culture and motivation) is significant to Employee Performance at PT. Perusahaan Gas Negara (Persero) Tbk Medan.

Research conducted by Yanti (2014) in a study entitled "The Influence of Leadership, Motivation, and Work Discipline of Employee Performance at PT. Patra Komala Di Dumai. In the study population and samples used amounted to 65 respondents, where independent variables Leadership (X1), Motivation (X2), and Work Discipline (X3) on Performance (Y). Effect of Work Discipline variable on performance at PT. Patra Komala has t count equal to 0,453 smaller than $t$ table equal to 1,66 or sign value $=0,652>\alpha=5 \%(0,652<0,05)$ stated Ha rejected. The conclusion that there is no significant influence between the Work Discipline on Performance at PT. Patra Komala.

The same study was also conducted by Sajangbati (2013) in a study entitled "Motivation, Discipline, and Satisfaction Influence on Employee Performance PT. Pos Indonesia (Persero) Bitung Branch ". In the study population used was 220 people, while the sample used was 69 people. Where the variables motivation (X1), discipline (X2), satisfaction (X3) and employee performance $(\mathrm{Y})$. It can be seen that the value of $\mathrm{R}$ square obtained is 0.942 . This figure means that $94.2 \%$ Employee performance is influenced by work motivation, Work discipline, and satisfaction while the rest of $5.8 \%$ is influenced by other reasons not examined in this study.

Similar research conducted by Dunggio (2013) entitled "Spirit and Discipline Work on Employee Productivity at PT. Jasa Raharja (Persero) Branch North Sulawesi ". In the research sample used amounted to 50 respondents from 56 people overall employees who are in the office of PT. Jasa Raharja (Persero) branch of North Sulawesi. Where variables education and training (X1), organizational culture (X2) and performance effectiveness (Y). Influence of variable Spirit and Work discipline to Work Productivity of PT. Jasa Raharja (Persero) Branch North Sulawesi simultaneously or together that is the variable spirit and work discipline against Work Productivity of employees of PT. Jasa Raharja (Persero) Branch North Sulawesi then with the results of calculations using F test obtained F arithmetic of 2.781 and when consulted with F table of 2.19. So F count is greater than F table. Then the hypothesis of the authors that allegedly variable work morale and work discipline simultaneously or together affect the Work Productivity of employees of PT. Jasa Raharja (Persero) North Sulawesi Branch can be proved true.

\section{Research Methodology}

This study is conducted at the disaster management and fire department in Palembang City, Indonesia. A survey research using questionnaire is employed to collect the data. The variables are education and training (X1), work discipline (X2), organizational culture (X3) and employees' performance (Y). Technology and labor force changes, service and performance improvement and rules' adjustment are indicators for education and training. Remuneration, supervision, and firmness are indicators for work discipline. Innovation, 
people oriented and composure are indicators for organizational culture. Working standard, work equipment and tool and work opportunity are indicators for employees' performance. The total population in this study is 360 respondents, and the sample size is 154 respondents that are determined using sample size formula. There are 7 offices in Palembang city and the sample is taken proportioned for each office.

\section{Findings}

The maturity of a person can be seen from the age of someone who is one of the factors that will affect the ability, knowledge, and responsibility of a person in acting, thinking and making decisions. For respondents with age under 30 years are 27 respondents with percentage $17,53 \%$, age 31 years to 40 years counted 103 respondents with percentage $66,88 \%$, age 41 years up to 50 years counted 24 respondents with percentage $15,8 \%$ and for ages above 51 years as much as zero percent or no respondents.

Recent education affects the ability, insight, and level of self-confidence of respondents in carrying out their work. This is because education is very important in order to improve its ability. Respondents with high school education equal to 72 respondents with the percentage of $46.75 \%$, diploma degree as many as 18 respondents with a percentage of $11.68 \%$, bachelor degree as many as 59 people with percentage $38.31 \%$, and for a master degree as many as 5 people with a percentage of $3.24 \%$.

The period of work also influences the respondents in doing their work. Respondent according to the working period under 5 years as many as 18 respondents with the percentage of $11.68 \%$, the working period of 6 years to 10 years as many as 29 respondents with the percentage of $18.83 \%$, the working period of 11 years to 15 years as many as 88 people with 57 respondents, $14 \%$, the working period of 16 years to 20 years as many as 18 respondents with $11.68 \%$, and the working period of 21 years to 30 years as many as 1 person with $00.64 \%$ respondents. The regression equation is presented in the table below.

\begin{tabular}{l|l|l|l|l}
\hline \multicolumn{2}{c}{ Coefficients $^{\mathrm{a}}$} \\
\multicolumn{2}{c}{ Model } & \multicolumn{2}{l}{$\begin{array}{l}\text { Unstandardized } \\
\text { Coefficients }\end{array}$} & $\begin{array}{l}\text { Standardized } \\
\text { Coefficients }\end{array}$ \\
\cline { 3 - 5 } \multicolumn{1}{c|}{} & B & Std. Error & Beta \\
\hline \multirow{4}{*}{1} & (Constant) & 4,338 & 2,397 & \\
\cline { 2 - 5 } & Pendidikan Pelatihan &, 052 &, 066 &, 060 \\
\cline { 2 - 5 } & Disiplin Kerja &, 017 &, 062 &, 021 \\
\cline { 2 - 5 } & Budaya Organisasi &, 402 &, 063 &, 490 \\
\hline
\end{tabular}

\section{a. Dependent Variable: VAR00004}

From the results of regression test processing above, it will get the result of regression equation that is $\mathrm{Y}=4,338+0,052 \mathrm{X} 1+0,017 \mathrm{X} 2+0,402 \mathrm{X} 3$, from result of equation can be interpreted that Constant value of 4,338 this means that without the influence of independent variables are training education variables (X1), work discipline (X2), organizational culture (X3), then the bound value of the performance of firefighters (Y) of 4,338 units. The value of 
0.052 is the regression coefficient which shows that if the value of training education variable (X1) is increased by one unit it will cause the increase of the value of the dependent variable that is the performance of firefighter $(\mathrm{Y})$ of 0.052 units. Thus it can be concluded that training education has a great influence on the performance variables of firefighters. The value of 0.017 is the regression coefficient which shows that if the work discipline variable (X2) is warned for one unit then it will cause the increase of the fire performance variable value of firefighter equal to 0,017 unit. This shows that the work discipline variable has a not too big influence on the performance variable of firefighters. Partially said that the organizational culture variable (X3) has a coefficient value of 0.402 this means that the organizational culture variables have a big influence on the performance of firefighters. This means that the organizational culture variable increased by one unit has increased the value of fire officer performance variable by 0,402 . Based on the results of the above output answers 154 respondents note that the performance variable firefighters tested not normally distributed with a significance value of 0.001 less than 0.05 , while for training education variables with a significance value of 0.065 , job discipline variables with a significance value of 0.072 and for organizational culture with a significance value of 0.074 , the value is greater than 0.05 so it can be concluded that the tested data is normally distributed.

\begin{tabular}{l|r|r|r|r}
\multicolumn{5}{|c}{ Model Summary } \\
\hline Model & \multicolumn{1}{|c|}{$\mathrm{R}$} & R Square & $\begin{array}{c}\text { Adjusted R } \\
\text { Square }\end{array}$ & Std. Error of the Estimate \\
\hline 1 &, $522^{\mathrm{a}}$ &, 273 &, 258 & 2,14214 \\
\hline
\end{tabular}

a. Predictors: (Constant), Budaya Kerja, Disiplin Kerja, Pendidikan Pelatihan

b. Dependent Variabel; Kinerja petugas pemadam

Description of the summary model table as follows: The correlation coefficient $(R)=0.522$. Based on the calculation of multiple correlation coefficients $(\mathrm{R})$ of 0.522 . The value can be increased by training education (X1), work discipline (X2), and organizational culture (X3) collectively on the performance variable of firefighter $(\mathrm{Y})$ and the correlation value $(\mathrm{R})$ can also be decreased the influence of training education variables (X1), work discipline (X2), and organizational culture (X3) collectively to the performance variable of firefighter (Y). Coefficient of determination (R2) or $\mathrm{R}$ Square $=0,273$. Training education variables $(\mathrm{X} 1)$, work discipline (X2), and organizational culture (X3) collectively contributed to the performance of firefighter (Y) of 0.273 or $27 \%$. The total contribution of the value of the independent variable is 0.273 or $27 \%$, while the rest is influenced by other variables besides the variables studied.

$\mathrm{F}$ test is used to find out whether training education variable $\mathrm{X} 1$, work discipline (X2), and organizational culture (X3) together significantly influence the performance variable of firefighter (Y) at the office of Disaster Management and Fire Agency of Palembang city by comparing the $\mathrm{F}$ arithmetic with $\mathrm{F}$ table or looking at the significance value of SPSS output results at alpha $0.05(5 \%)$. 


\begin{tabular}{rl|r|r|r|r|r}
\multicolumn{7}{c}{ ANOVA $^{\text {a }}$} \\
\hline Model & & Sum of Squares & \multicolumn{1}{c}{ df } & Mean Square & \multicolumn{1}{c}{ F } & \multicolumn{1}{c}{ Sig. } \\
\hline \multirow{2}{*}{1} & Regression & 257,951 & 3 & 85,984 & 18,738 &, $000^{\text {b }}$ \\
& Residual & 688,315 & 150 & 4,589 & & \\
& Total & 946,266 & 153 & & & \\
\hline
\end{tabular}

a. Dependent Variable: Kinerja Pemadam

b. Predictors: (Constant), Budaya Organisasi, Disiplin Kerja, Pendidikan Pelatihan

Based on the above table obtained F count value of 18.738> Ftable of 2.66 and p_value value (Sig) of $0.000<0.05$. Thus it can be concluded that Ha accepted and Ho rejected, this means there is a significant influence between training education (X1), work discipline (X2), and organizational culture (X3) collectively to the performance variables firefighters Disaster Relief Agency and Fire Department of Palembang city. Thus the accepted research hypothesis that states there is the influence of training education, work discipline and organizational culture on the performance of firefighters at the Office of Disaster Management and Fire Agency of Palembang City. Then the calculation coefficient of determination results is if training education, work discipline, and organizational culture together increased by $100 \%$, it can improve the performance of firefighters Palembang city by $25.8 \%$ and vice versa. Based on the determination coefficient test, it can be explained that the variables used in this study are sufficient to explain the performance of firefighters at the Office of Disaster Management and Fire Agency of Palembang city can be improved by improving training education, improving the discipline of firefighters and improve organizational culture for the better.

Furthermore, if seen from the value of R Square is that the performance (Y) firefighters city of Palembang can be explained by training education, work discipline and organizational culture of $27.3 \%$; while the rest of $72.7 \%$ is explained by other factors not included in this study, such as job placement, motivation, leadership, compensation, organizational climate, competence and many other factors. Then based on the description of the data on the research instrument on the performance variable of the firefighter, explained that the respondent's answer which stated the highest agree is on item 1 where the fire truck is difficult to reach the location because the narrow road and the remote location go inside. and respondents' answers stated that strongly agree the highest is in item 3, that firefighters are protected with self-safety insurance to protect themselves from accidents. Performance is about what to do and how to do it. Essentially how to manage all the organization's activities to achieve organizational goals that have been established. Each variable in the organization of the agency or service should include a range of individual indicators such as capabilities and skills, background, social and cultural, demographic, while organization: such as general organization policy, reward system, career system, and work system. Performance is a view of how firefighters work in an agency by looking at the productivity of firefighters, the quality of work, the quantity of work and responsibility. Improved performance of firefighters does not happen by itself but is influenced by other factors such as good training education, high work discipline, and good organizational culture. 
The t-test is used to find out whether the independent variables are partially significant to the dependent variable. In this research, the t-test is used to find out whether training education variables (X1), work discipline (X2) and organizational culture (X3) have significant influence to performance variable of firefighter (Y) Disaster Management and Fire Agency of Palembang city. The t-test is done by looking at Probability (P-value) and $t$ arithmetic against t table.

\begin{tabular}{|c|c|c|c|c|c|c|}
\hline \multicolumn{7}{|c|}{ Coefficients $^{\mathrm{a}}$} \\
\hline \multicolumn{2}{|c|}{ Model } & \multicolumn{2}{|c|}{ Unstandardized Coefficients } & \multirow{2}{*}{$\begin{array}{c}\text { Standardized } \\
\text { Coefficients } \\
\text { Beta }\end{array}$} & \multirow[t]{2}{*}{$\mathrm{t}$} & \multirow[t]{2}{*}{ Sig. } \\
\hline & & $\mathrm{B}$ & Std. Error & & & \\
\hline \multirow[b]{2}{*}{1} & (Constant) & 16,626 & 1,662 & & 10,004 &, 000 \\
\hline & $\begin{array}{l}\text { Pendidian } \\
\text { pelatihan }\end{array}$ &, 214 & ,068 & ,248 & 3,150 &, 002 \\
\hline
\end{tabular}

a. Dependent Variable: Kinerja pemadam

Based on the result of t-test above for training education variable (X1) with t count of 3,150> t table 1,975 then p_value (sig) 0,002 <from 0,05 which means Ho refused and Ha accepted this indicates that at $95 \%$ confidence stated training education (X1) has a significant influence on the performance of firefighter (Y). Based on the results of a partial test of training education variables have a positive effect on the performance of firefighters at the office of disaster management agencies and firefighters of Palembang city. This study supports previous research conducted by Aulia (2014) which states that education and training have a positive effect on the performance of inpatient nurses. Then, based on multiple linear regression test result, it is found that if the training education at the office of disaster management and fire department of Palembang city increased by $100 \%$, it can improve the performance of firefighters of Palembang city by $5.2 \%$ and vice versa. Based on the value of regression coefficient and significant level, it can be concluded that $\mathrm{H} 0$ rejected and $\mathrm{Ha}$ accepted means there is a positive influence of training education on the performance of firefighting agencies disaster management agencies and firefighters Palembang city, so the hypothesis can be accepted.

Then based on the description of the data on the research instrument on the training education variables, explaining that the respondent's answer stated that the highest approval is on item 6 where the regulation changes make the firefighter perform the rescue action on the fire victims and respondent's answer stating strongly agree highest on item 1 that firefighters were able to adjust to the changes of the new fleet. Training education needs to be provided by firefighters to be able to understand and work optimally, thus making the work of firefighters will be more smoothly and the performance of the firefighter's increases as well. By analyzing the need for better training in training and designing instructions appropriately, will improve the performance of firefighters in Palembang city, whereas if training education gets worse or has a negative impact then the performance of firefighters of Palembang city will decrease. 


\begin{tabular}{|c|c|c|c|c|c|c|}
\hline \multicolumn{7}{|c|}{ Coefficients $^{\mathrm{a}}$} \\
\hline \multicolumn{2}{|c|}{ Model } & \multicolumn{2}{|c|}{ Unstandardized Coefficients } & \multirow{2}{*}{$\begin{array}{c}\text { Standardized } \\
\text { Coefficients } \\
\text { Beta } \\
\end{array}$} & \multirow[t]{2}{*}{$\mathrm{t}$} & \multirow[t]{2}{*}{ Sig. } \\
\hline & & $\mathrm{B}$ & Std. Error & & & \\
\hline \multirow{2}{*}{1} & (Constant) & 18,679 & 1,376 & & 13,575 &, 000 \\
\hline & Disiplin Kerja &, 154 &, 066 &, 184 & 2,310 &, 022 \\
\hline
\end{tabular}

a. Dependent Variable: Kinerja petugas pemadam

Based on the result of $t$-test above for work discipline variable (X2) with $t$ count 2,310> $t$ table 1,975 then $\mathrm{p}_{-}$value ( $\mathrm{sig}$ ) equal to 0,022 <from 0,05 which means Ho refused and Ha accepted this indicates that at $95 \%$ confidence stated work discipline (X2) has a significant influence on the performance of firefighter (Y). From the results of the partial test for work discipline variables have a positive effect on the performance of firefighters at the office of disaster management agencies and firefighters Palembang city. This study also supports previous research conducted by Sajangbati (2013) stating that the discipline has a positive effect on employee performance. Then, based on multiple linear regression test result, it is found that if the firefighting work of firefighters and fire brigade firefighters increased by $100 \%$, it could improve firefighters' performance by $1.7 \%$ and vice versa. Based on the value of regression coefficient and significant level, it can be concluded that $\mathrm{HO}$ rejected and $\mathrm{Ha}$ accepted means there is a positive influence of work discipline on the performance of firefighting agencies disaster management agencies and firefighters Palembang city, so the hypothesis can be accepted. Then based on the description of the data on the research instrument on the work discipline variables, explaining that the respondent's answer which states the highest approval is on item 4 where firefighters are given punishment sanction if violating the rules that are educational and respondent's answer which states strongly agree the highest is in item 2, that firefighters are always reminded of wear and use of safety equipment.

Humans as social beings who need a lot of things that are not limited. To work the maximum results of firefighters need work discipline or encouragement from various facets. Work discipline is the result of a process that is internal or external to the individual that causes the attitude of enthusiasm and consistency in terms of doing certain activities. Work discipline is very important in a firefighter, with a firefighter working discipline expected to work hard and enthusiastic in achieving better performance. The results of this study indicate work discipline has a positive effect on the performance, in line with the importance of work discipline given to firefighters, the higher the discipline of work within a person the higher the performance is displayed. Salary is a physical requirement for firefighters, with salaries that can meet the needs of family economics, firefighters will be more enthusiastic about the work so as to improve the performance of firefighters. In addition, maintaining good social relationships among colleagues is also required to create a conducive working environment, with a conducive working environment, the performance of firefighters will also increase as well as the need for awards from the work of firefighters, if the work of officers firefighters at minimum value by their superiors then firefighters will feel happy and feel disciplined to work better. 


\begin{tabular}{|c|c|c|c|c|c|c|}
\hline \multicolumn{7}{|c|}{ Coefficients $^{\mathrm{a}}$} \\
\hline \multicolumn{2}{|c|}{ Model } & \multicolumn{2}{|c|}{ Unstandardized Coefficients } & \multirow{2}{*}{$\begin{array}{c}\text { Standardized } \\
\text { Coefficients } \\
\text { Beta }\end{array}$} & \multirow[t]{2}{*}{$\mathrm{t}$} & \multirow[t]{2}{*}{ Sig. } \\
\hline & & $\mathrm{B}$ & Std. Error & & & \\
\hline \multirow{2}{*}{1} & $($ Constant $)$ & 5,036 & 2,254 & & 2,235 &, 027 \\
\hline & Budaya Organisasi & ,425 & 057 &, 518 & 7,472 &, 000 \\
\hline
\end{tabular}

a. Dependent Variable: Kinerja Pemadam

Based on the result of t-test above for organizational culture variable (X3) with t count of $7,472>\mathrm{t}$ table 1,975 then $\mathrm{p}_{-}$value ( $\mathrm{sig}$ ) equal to 0.000 <from 0,05 meaning Ho refused and $\mathrm{Ha}$ accepted this indicates that at $95 \%$ confidence stated organizational culture (X3) has a significant influence on the performance of firefighters (Y). Partial test results for organizational culture variables significantly affect the performance of firefighting agencies disaster management agencies and firefighters Palembang city. Then based on the result of multiple linear regression tests it is found that if the organizational culture at the office of Disaster Management and Fire Agency of Palembang city increased by $100 \%$, it can improve the performance of firefighters by $40.2 \%$ and vice versa.

Based on the value of regression coefficient and significant level, it can be concluded that H0 rejected and $\mathrm{Ha}$ accepted means there is a positive influence of organizational culture on the performance of firefighters Fire and Disaster Management Agency of the city of Palembang, so the hypothesis can be accepted. Then based on the description of the data on the research instrument on organizational culture variables, explaining that the respondent's answer that states the highest approval is on item 2 where during the operation of the firefighters team can generate new ideas in carrying out their duties and respondents answer that states strongly agree the highest on item 4 that honesty in work is the main capital owned by firefighters.

Organizational culture is a series of customs of the behavioral behavior of all firefighters that can be changed and upgraded from time to time and from one worker to another. This can be seen from the behavior of firefighters when there is difficulty in the completion of work, between firefighters, help each other and very rare conflicts among firefighters associated with work, otherwise when the culture of the organization that arises contrary to the goals, needs, and personal motivation, it is certain that both achievement and work will be reduced. Organizational culture is something that is done continuously and in a long time used by the firefighter where he worked, therefore maintaining or improving attitudes and behaviors in organizational culture is better required for the performance of firefighters Disaster Management Agency and Fire firefighting Palembang city gets better, on the contrary, if organizational culture decreases or worsens then firefighters performance of Disaster Management Agency and Fire Department of Palembang city will decrease.

\section{Conclusions}

It can be concluded that there is a positive and significant effect of education and training, work discipline and organizational culture on employee's performance. To always increase 
the knowledge in the field of training education to firefighters, so that firefighters understand/understand with the task and responsibility with the work given to him so that the work of firefighters will be maximized. In order to always maintain and even improve the work discipline of each fire department personnel at the disaster management and fire agency of Palembang city, provide a written and oral reprimand to a non-disciplined firefighter in the work and give praise to the firefighting personnel of firefighters work well.

Always maintain, maintain and enhance a good organizational culture between the commander of the guard with firefighters, in working during working hours it is better for firefighters to maintain the attitude and behavior with the leadership whether it is head section, head of field or head of service at work, because if not maintained will disrupt the good relationship that has been created between the leadership with subordinates.

\section{References}

Aulia, R. (2014). Pengaruh Pendidikan dan Pelatihan, Kepuasan Kerja, Kepemimpinan terhadap Kinerja Perawat Rawat Inap RSUD Kabupaten Siak [The impact of education and training, satisfaction and leadership on employees' performance of RSUD Kabupaten Siak]. Jurnal Tepak Manajemen Bisnis, 6(2), 63-72.

Dunggio, M. (2013). Semangat dan disiplin kerja terhadap produktivitas kerja karyawan pada PT. Jasa Raharja (Persero) Cabang Sulawesi Utara [Spirit and work discipline on employees' productivity in the Jasa Raharja Sulawesi Utara Branch]. Jurnal EMBA, 1(4), 523-533.

Edison, E., Anwar, Y., \& Komariyah, I. (2016). Manajemen sumber daya manusia strategi dan perubahan dalam rangka meningkatkan kinerja pegawai dan organisasi [Human resource management strategy and change in order to increase employees' performance and organisational's performance]. Bandung: Alfabeta.

Gultom, D. K. (2014). Pengaruh budaya organisasi perusahaan dan motivasi terhadap kinerja karyawan pada PT. Perusahan Gas Negara (Persero) Tbk Medan [The impact of organizational culture and motivation on employees' performance in the Perusahaan Gas Negara Medan. Jurnal Manajemen dan Bisnis, 14(2), 176-184.

Hariandja, M. T. E. (2009). Manajemen sumber daya manusia [Human resource management]. Jakarta, Indonesia: PT. Gramedia Widiasarana Indonesia.

Hasibuan, M. S. P. (2010). Manajemen sumber daya manusia [Human resource management]. Jakarta, Indonesia: PT. Bumi Aksara.

Kowaas, M. P., Sepang, J. L., \& Taroreh, R. N. (2016). Pengaruh pendidikan, pelatihan, dan disiplin kerja terhadap kinerja karyawan pada Badan Penanggulangan Bencana Daerah Provinsi Sulawesi Utara [ The impact of education, training and work discipline on employees' performance at the Regional Disaster Management Unit of North Sulawesi Province]. Jurnal Berkala Ilmiah Efisiensi, 16(3), 50-61. 


\section{Macrothink}

International Journal of Human Resource Studies

ISSN 2162-3058 2018, Vol. 8, No. 3

Sajangbati, I. A. S. (2013). Motivasi, disiplin, dan kepuasan pengaruhnya terhadap kinerja pegawai PT. Pos Indonesia (Persero) cabang Bitung [Motivation, discipline and satisfaction on employees' performance in the Indonesian Post Bitung Branch. Jurnal EMBA. 1(4), 667-668.

Sedarmayanti. (2014). Sumber daya manusia dan produktivitas kerja [Human resource management and work productivity]. Jakarta: Mandar Maju.

Sunyoto, D., \& Burhanudin. (2011). Perilaku organisasi [Organizational behavior]. Yogyakarta: CAPS.

Sutrisno, E. (2016). Manajemen sumber daya manusia [Human resource management]. Jakarta: Kencana Prenada Media Group.

Wibowo. (2016). Manajemen kinerja [Performance management]. Jakarta, Indonesia: PT Raja Grafindo Persada.

Yanti, K. S. (2014). Pengaruh kepemimpinan, motivasi dan disiplin kerja terhadap kinerja karyawan pada PT. Patra Komala Sari di Dumai [The impact of leadership, motivation and work discipline on employees' performance of Patra Komala Sari Dumai]. Jurnal Tepak Manajemen Bisnis, 6(2), 119-127.

\section{Copyright Disclaimer}

Copyright for this article is retained by the author(s), with first publication rights granted to the journal.

This is an open-access article distributed under the terms and conditions of the Creative Commons Attribution license (http://creativecommons.org/licenses/by/4.0/). 